\title{
Testostérone et fertilité chez les taureaux Blanc Bleu Belge et Pie noire
}

\author{
R. RENAVILLE (1), J. FABRY (2), A. BURNY (1) \\ (1) Faculté des Sciences agronomiques, Chaire de Zootechnie, \\ B-5800 Gembloux, Belgique \\ (2) Centre de Recherches agronomiques, Station de Zootechnie, \\ route de Liroux, B-5800 Gembloux, Belgique
}

La sélection du caractère viandeux dans la race Blanc Bleu Belge $(B B B)$ entraine une baisse de la fertilité. Nous avons étudié l'évolution de la testostérone (T) dans cette race.

Le classement des diverses souches de $B B B$, établi selon la quantité moyenne de $T$ dans. chaque lot de descendants est proche de celui opéré chez les pères selon le pourcentage de non retour à 60-90 jours. Les taureaux sexuellement peu précoces présentent un retard d'environ un mois dans l'apparition des pulsations de T. Toutefois, une majorité des $B B B$ de type culard présente des profils de $\mathrm{T}$ avec des pics dès 130 à 150 jours.

\section{Genetic aspects of lymphatic leukaemia in dairy cattle}

\author{
Krystyna M. CHARON \\ Agricultural University, Institute of the Biological Basis of Animal Breeding, \\ ul.Przejazd 4, 05-840 Brwinóv, Poland
}

Basing on the results of the routine veterinary haematological tests conducted several times on 6944 cows of Black-and-White breed, the correlations between parentage of these animals from sires (total 73 half-sib groups) and dam (462 pairs of dam-daughter) and their susceptibility to lymphatic leukaemia were analysed.

Statistically significant differences were found in the frequency of leukaemia cases. The heritability to resistance to lymphatic leukaemia was estimated using the method of dam-daughter regression as well as the method of variance analysis from the sire components. The values of the heritability coefficients were 0.78 and 0.26 respectively.

\section{Red Holstein immigration in Czech Pied through selection programme}

\author{
J. VÁCHAL, J. PŘIBYL \\ Research Institute of Animal Production, Praha-Uhrí̌eves, Czechoslovakia
}

The improvement of the Czech Pied cattle is carried out within the complex selection programme by mating the Red Holstein and crossbred bulls with the Pied mothers of bulls ; their male progenies are strictly positively selected. Current evaluation demonstrated an increase in milk production through this gene immigration, the individuality of the breeding value of bulls, and a positive genetic trend of the applied selection programme in the Czech Pied cattle. The evaluation was performed by the improved herd-mate method after Pribyl and Váchal (1979) which takes into account the genetic levels of contemporary cows and the performance levels in herds. 